\title{
UJI AKTIVITAS ANTIMIKROBA EKSTRAK DAN FRAKSI KARANG LUNAK (Sarcophyton sp.) DARI PERAIRAN PULAU BANGKA LIKUPANG TERHADAP PERTUMBUHAN MIKROBA Staphylococcus aureus, Salmonella tyhpimurium, DAN Candida albicans
}

\section{ANTIMICROBIAL ACTIVITY TEST OF EXTRACTS AND FRACTION OF SOFT CORAL (Sarcophyton sp.) FROM BANGKA ISLAND WATERS LIKUPANG AGAINTS MICROBIAL GROWTH OF Staphylococcus aureus, Salmonella typhimurium, AND Candida albicans}

\author{
Mochamad I. Eda ${ }^{1)}$, Defny S Wewengkang ${ }^{1)}$, Surya Sumantri ${ }^{1)}$ \\ 1) Program Studi Farmasi FMIPA UNSRAT Manado, 95115 \\ *m.ilhameda@gmail.com
}

\begin{abstract}
Sarcophyton sp. is able to produce bioactive materials, the bioactive material contained in Sarcophyton sp., is sarcophine. The purpose of this study is to find out whether the extracts from soft coral Sarcophyton sp., in Bangka Island waters Likupang performed antimicrobial activity against several pathogenic microbes, such as Staphylococcus aureus, Salmonella typhimurium, and Candida albicans. Samples were extracted by maceration method with ethanol solvent and the fractionation method used was liquid-liquid.The antimicrobial activity testing method used in this study is the Kirby and Bauer disc diffusion method. The results obtained from the antimicrobial activity test on Staphylococcus aureus, fractions of n-hexane with result $8.27 \mathrm{~mm}$ and fractions of chloroform $8.41 \mathrm{~mm}$. In Candida albicans, the n-hexane fraction has an $8.18 \mathrm{~mm}$ and the chloroform fraction 8.06. While for Salmonella typhimurium has no activity. The conclusion of this study it was found that only some fractions have antimicrobial activity and categorized as moderate, such as the fractions of n-hexane and chloroform that only have moderate inhibiting activity against Stapphylococcus aureus and Candida albicans while for Salmonella typhimurium, the extracts and fractions of Sarcophyton sp., has no activity to the way to inhibit these bacteria.
\end{abstract}

Keywords: Sarcophyton sp., Antimicrobial, Staphylococcus aureus, Salmonella tyhpimurium, Candida albicans

\begin{abstract}
ABSTRAK
Sarcophyton sp. mampu menghasilkan bahan bioaktif, bahan bioaktif yang terdapat pada Sarcophyton sp adalah sarcophine. Tujuan dari penelitian ini yaitu untuk mengetahui apakah ekstrak dari Karang Lunak Sarcophyton sp.,di Perairan Pulau Bangka Likupang memiliki aktivitas antimikroba terhadap beberapa mikroba patogen Staphylococcus aureus, Salmonella typhi, dan Candida albicans. Sampel diekstraksi dengan metode maserasi dengan pelarut etanol dan metode fraksinasi yang digunakan yaitu fraksinasi cair cair. Metode pengujian aktivitas antimikroba yang digunakan dalam penelitian ini yaitu metode difusi agar (disc diffusion Kirby and Bauer). Hasil yang didapat dari uji aktivitas antimikroba pada bakteri Staphylococcus aureus, fraksi n-heksan mendapatkan hasil 8.27mm dan pada fraksi kloroform $8.41 \mathrm{~mm}$. Pada jamur Candida albicans, fraksi n-heksan mendapatkan hasil 8.18mm dan pada fraksi kloroform 8.06mm, sedangkan pada bakteri Salmonella typhi tidak memiliki aktivitas. Kesimpulan dari penelitian ini, hanya sebagian fraksi yang memiliki aktivitas untuk penghambat antimikroba dengan dikategorikan sedang, seperti pada fraksi n-heksan dan klorofom pada bakteri Stapphylococcus aureus dan jamur Candida albicans, sementara untuk bakteri Salmonella tyhpi ekstrak dan fraksi sampel Karang Lunak Sarcophyton sp. tidak memiliki aktivitas untuk menghambat bakteri tersebut.
\end{abstract}

Kata Kunci : Sarcophyton sp., antimikroba, Staphylococcus aureus, Salmonella tyhpimurium, Candida albicans 


\section{PENDAHULUAN}

Sarcophyton sp. adalah salah satu jenis karang lunak yang mampu menghasilkan bahan bioaktif. Bahan bioaktif yang terdapat pada Sarcophyton sp. adalah sarcophine. Namun masalah serius dalam pengembangan senyawa bioaktif dari karang lunak adalah masalah suplai, karena untuk mendapatkan sejumlah relatif kecil senyawa bioaktif, diperlukan sejumlah besar karang lunak (Huda, 2011). Senyawa kimia aktif yang terdapat pada karang lunak Sarcophyton sp., menunjukkan aktivitas sebagai antimikroba, antibakteri, anti fungi, anti tumor, neurotoksik, dan anti inflamantori yang bermanfaat bagi industri farmasi (Sawant, 2006).

Antimikroba merupakan senyawa alami, semi sintetik yang menghalangi atau menghambat organisme bersifat komensal atau patogenik. Dengan sedikit atau tidak ada kerugian pada inangnya. Antimikroba diklasifikasikan berdasarkan spektrumnya, mekanisme aksi, strain penghasil, cara biosintesis, maupun struktur biokimianya (Brooks et al., 2005).

Staphylococcus aureus merupakan bakteri Gram positif berbentuk bulat, tersusun dalam kelompok-kelompok yang tidak teratur seperti buah anggur, fakultatif anaerob, tidak membentuk spora dan tidak bergerak. Bakteri ini tumbuh pada suhu optimum $37^{\circ} \mathrm{C}$, tetapi membentuk pigmen paling baik pada suhu kamar $\left(20-25{ }^{\circ} \mathrm{C}\right)$. Koloni pada perbenihan padat berwarna abu-abu sampai kuning keemasan, berbentuk bundar, halus, menonjol dan berkilau (Brooks et al., 1995).

Salmonella typhi merupakan bakteri yang berbentuk batang, tidak berspora, memiliki ukuran lebar antara 0,7 - 1,5 $\mu \mathrm{m}$ dan panjang 2,0 - 5,0 $\mu \mathrm{m}$, besar koloni rata-rata $24 \mathrm{~mm}$, dominan bergerak dengan flagel peritrik dan termasuk bakteri gram negatif (Batt \& Tortorello, 2014).

Candida merupakan jamur yang mempunyai kemampuan untuk tumbuh dalam dua bentuk yang berbeda yaitu blastopore (blasroconidia) adalah bentuk fenotip yang bertanggung jawab dalam tranmisi dan penyebaran, serta germinated yeast. Oleh karena itu Candida disebut jamur dimorfik (Tortora, 2001). Perbedaan ini tergantung pada faktor eksternal yang mempengaruhi selama proses pertumbuhan berlangsung. Bentuk fenotip dapat menginvasi jaringan dan menimbulkan simptomatik karena dapat menghasilkan mycelia (Wibowo, 2010).

Pada penelitian ini dilakukan uji aktivitas antimikroba ekstrak dan fraksi karang lunak Sarcophyton sp. yang diambil dari Perairan Pulau Bangka Likupang dengan menggunakan metode difusi agar (disc diffu sion Kirby and Bauer).

\section{METODOLOGI PENELITIAN Waktu dan Tempat Penelitian}

Penelitian ini dilaksanakan pada bulan November 2019 - Juni 2020 di laboratorium penelitian lanjutan Program studi Farmasi, Fakultas Matematika dan Ilmu Pengetahuan Alam, Universitas Sam Ratulangi.

\section{Bentuk Penelitian}

Bentuk penelitian ini ialah eksperimen laboratorium yang akan menguji komponen yang diekstrak dari Karang Lunak Sarcophyton sp., yang diperoleh dari perairan Pulau Bangka Likupang Kabupaten Minahasa Utara.

\section{Alat dan Bahan}

Alat

Alat yang digunakan dalam penelitian ini yaitu masker, sarung tangan, pisau, gunting, telenan,scuba diving,kamera, kantong plastik, alat-alat gelas, rotary evaporator, timbangan analitik, wadah kaca, cawan petri, autoklaf, pinset, pembakar spritus, magnetic steerer, pipet tetes,corong pisah, batang pengaduk, Laminar Air Flow, lemari pendingin, incubator, kertas cakram, desikator, mikropipet, jangka sorong (kaliper), label, spidol permanen, tissue, aluminium foil, kertas saring, kapas

\section{Bahan}

Bahan-bahan yang digunakan yaitu Karang Lunak Sarcophyton sp., mikroba uji Staphylococcus aureus, Salmonella typhi, dan Candida albicans, etanol 96\%, akuades, 
metanol, n-heksan, kloroform, nutrient broth, nutrien agar, potato dextrose agar, Kloramfenikol.

\section{Prosedur Penelitian}

\section{Pengambilan dan Preparasi Sampel}

Sampel Karang Lunak Sarcophyton sp. diambil di perairan Pulau Bangka Likupang Kabupaten Minahasa Utara menggunakan alat bantu masker, tabung udara, snorkel dan fins. Sampel difoto kemudian diambil dan dimasukan kedalam kantong plastik. Kemudian sampel dirajang atau dipotong kecil-kecil dengan ukuran 1 $\mathrm{cm}^{2}$ dan dimasukan kedalam botol lalu diekstraksi dengan metode maserasi dengan menggunakan etanol 96\% lalu diberi label serta nomor sampel, kemudian langsung dibawa ke Laboratorium Fitokimia dan Farmakognosi Program Studi Farmasi Universitas Sam Ratulangi.

\section{Ekstraksi dan Fraksinasi Ekstraksi}

Ekstrak Karang Lunak Sarcophyton sp., diekstraksi dengan menggunakan cara maserasi. Sampel dipotong kecil-kecil dengan ukuran $1 \mathrm{~cm}^{2}$ lalu dimasukkan ke dalam botol dan direndam dengan larutan etanol 96\% sampai sampel terendam secara keseluruhan dan dibiarkan selama 24 jam. Sampel yang direndam disaring dengan menggunakan kertas saring menghasilkan filtrat 1 dan debris 1. Debris 1 direndam dengan larutan etanol 96\% sampai sampel terendam secara keseluruhan kemudian dibiarkan selama 24 jam. Sampel tersebut disaring menggunakan kertas saring menghasilkan filtrat 2 dan debris 2. Debris 2 kemudian direndam dalam larutan etanol $96 \%$ sampai sampel terendam secara keseluruhan dan dibiarkan selama 24 jam, sampel tersebut disaring menggunakan kertas saring menghasilkan filtrat 3 dan debris 3 . Filtrat 1, 2 dan 3 dicampur menjadi satu kemudian disaring, lalu dievaporasi menggunakan rotary evaporator sehingga didapat ekstrak kasar Karang Lunak Sarcophyton sp., kemudian ditimbang menggunakan timbangan analitik, diperoleh ekstrak etanol sampel sebanyak $95 \mathrm{~g}$.
Selanjutnya ekstrak etanol Karang Lunak Sarcophyton sp., digunakan dalam fraksinasi dan pengujian antimikroba.

\section{Fraksinasi}

Ekstrak etanol Karang Lunak Sarcophyton sp., dimasukkan ke dalam Erlenmeyer kemudian dilarutkan dengan metanol $80 \%$ sebanyak $100 \mathrm{ml}$. Setelah sampel larut, sampel dimasukkan ke dalam corong pisah dan ditambahkan pelarut nheksan sebanyak $100 \mathrm{~mL}$. Setelah itu dikocok dalam corong pisah sampai homogen. Sampel dibiarkan hingga membentuk lapisan metanol dan lapisan n-heksan. Masing-masing lapisan metanol dan lapisan n-heksan ditampung di dalam wadah yang berbeda. Lapisan n-heksan selanjutnya dievaporasi menggunakan rotary evaporator hingga kering, lalu ditimbang dengan timbangan analitik dan diperoleh fraksi n-heksan. Selanjutnya lapisan metanol ditambahkan dengan akuades $100 \mathrm{ml}$, kemudian dipartisi dengan pelarut kloroform menggunakan perbandingan $1: 1 \mathrm{v} / \mathrm{v}$ setelah itu dikocok dalam corong pisah hingga homogen. Lapisan metanol dibiarkan hingga membentuk dua lapisan yaitu lapisan metanol dan lapisan kloroform. Masing-masing lapisan metanol dan lapisan kloroform ditampung ke dalam wadah yang berbeda. Lapisan kloroform dievaporasi menggunakan rotary evaporator hingga kering lalu ditimbang dengan timbangan analitik dan diperoleh fraksi kloroform. Lapisan metanol yang ditampung pada wadah lain dievaporasi menggunakan rotary evaporator hingga kering lalu ditimbang dengan timbangan analitik dan diperoleh fraksi metanol. Ketiga fraksi yang diperoleh akan digunakan dalam pengujian antimikroba.

\section{Sterilisasi Alat}

Alat-alat yang digunakan dalam penelitian aktivitas antimikroba ini disterilkan terlebih dahulu. Alat-alat gelas disterilkan dengan autoklaf pada suhu $121^{\circ} \mathrm{C}$ selama 15 menit, pinset dibakar dengan pembakaran diatas api langsung dan media disterilkan diautoklaf pada suhu $121^{\circ} \mathrm{C}$ selama 15 menit (Mpila, 2012). 


\section{Pembuatan Media Cair}

Bahan-bahan yang digunakan ditimbang seperti pepton 0,5 gram, beef extract 0,3 gram, $\mathrm{NaCl} 0,3$ gram dimasukkan dalam erlenmeyer lalu ditambahkan aquades $100 \mathrm{ml}$. Erlenmeyer yang telah berisikan bahan diaduk hingga homogen lalu ditutup dengan kertas alumunium foil, kemudian dimasukkan ke dalam autoklaf untuk disterilkan pada suhu $121^{\circ} \mathrm{C}$ selama 15 menit ( Pasodung et al., 2018).

\section{Pembuatan Media Uji}

Pepton $0,5 \mathrm{~g}$, beef extract $0,3 \mathrm{~g}, \mathrm{NaCl}$ 0,3 g, agar 1,5 g,dan akuades sebanyak 100 $\mathrm{ml}$ diaduk sampai homogen kemudian disterilkan dalam autoklaf pada suhu $121^{\circ} \mathrm{C}$ selama 15 menit dan setelah itu didinginkan. Setelah dingin, media cair B1 di tutup dengan aluminium foil (Dwijendra et al, 2014).

\section{Pembuatan Kontrol Positif dan Negatif}

Kontrol positif dalam pengujian aktivitas antimikroba ini menggunakan kloramfenikol paper disc. Kontrol negatif yang digunakan dalam penelitian ini yaitu menggunakan pelarut metanol, dengan cara membuat larutan stok metanol dengan mengambil sebanyak $200 \mu \mathrm{L}$ metanol kemudian di totolkan pada paper disc (Lalamentik, 2017).

\section{Pembuatan Larutan Uji}

Dibuat larutan uji dengan cara ditimbang ekstrak kasar karang lunak sebanyak $1 \mathrm{mg}$, kemudian dilarutkan dalam $200 \mu \mathrm{L}$ metanol, sehingga menghasilkan konsentrasi larutan uji sebesar $250 \mu \mathrm{g} / 50 \mu \mathrm{L}$. Perlakuan yang sama dilakukan pada fraksi nheksan, fraksi kloroform dan fraksi metanol (Ortez, 2005).

\section{Kultur Mikroba}

Bakteri yang akan digunakan yaitu Staphylococcus aureus dan Salmonella tyhpi dan Candida albicans. Bakteri dan jamur yang akan dikultur diambil dari lemari pendingin kemudian dipipet sebanyak $100 \mu \mathrm{L}$ kedalam masing-masing tabung reaksi berisi media cair sebanyak $1 \mathrm{~mL}$, kemudian ditutup dengan menggunakan aluminium foil dan diinkubasi dalam inkubator pada suhu $37^{\circ} \mathrm{C}$ selama 24 jam (Ortez, 2005).

\section{Pengujian Aktivitas Antimikroba}

Metode yang digunakan dalam penelitian ini yaitu metode difusi agar (disc diffusion Kirby and Bauer). Pada pengujian aktivitas antimikroba ini, cakram (paper disc) yang digunakan berukuran $6 \mathrm{~mm}$ dengan daya serap $50 \mu \mathrm{L}$ tiap cakram. Sebanyak $300 \mu \mathrm{L}$ mikroba yang telah dikultur, dipipet dan diinokulasi pada $30 \mathrm{ml}$ media agar lalu diaduk hingga homogen dan kemudian dituangkan ke dalam cawan petri dan tunggu sampai media agar mengeras. Kemudian, larutan uji yang telah disiapkan ditotolkan pada masingmasing cakram dengan menggunakan mikropipet. Setelah agar mengeras, kertas cakram yang telah ditotolkan sampel karang lunak Sarcophyton sp. kontrol positif dan kontrol negatif diletakkan ke dalam cawan petri dengan menggunakan pinset. Selanjutnya, cawan petri diberi label dan diinkubasi dalam inkubator pada suhu $37^{\circ} \mathrm{C}$ selama 1 x 24 Jam (Ortez, 2005).

\section{Pengamatan dan Pengukuran Diameter Zona Hambat}

Pengamatan dilakukan setelah 24 jam masa inkubasi. Daerah pada sekitaran cakram menunjukkan kepekaan bakteri terhadap antibiotik atau bahan antibakteri yang digunakan sebagai bahan uji yang dinyatakan dengan diameter zona hambat/bunuh. Diameter zona hambat diukur dalam satuan millimeter ( $\mathrm{mm}$ ) menggunakan jangka sorong dengan cara diukur diameter total zona bening/keruh cakram. Kemudian diameter zona hambat tersebut dikategorikan kekuatan daya anti bakterinya berdasarkan penggolongan (Davis dan Stout, 1971). 


\section{HASIL DAN PEMBAHASAN}

Hasil

Tabel 1. Randemen fraksi karang lunak Sarcophyton $s p$.

\begin{tabular}{ccccc}
\hline No & Sampel & Berat $(\mathbf{g})$ & Rendemen $(\boldsymbol{\%})$ & Warna \\
\hline 1. & EE & 12,57 & 0,13 & hitam \\
\hline 2. & FH & 0,55 & 0,27 & hijau \\
\hline 3. & FK & 0,20 & 0,10 & Coklat \\
\hline 4. & FM & 0,80 & 0,40 & kuning
\end{tabular}

Tabel 2. Hasil pengukuran diameter zona hambat ekstrak dan fraksi Sarcophyton sp. terhadap Stapphylococcus aureus, Salmonella thypimurium dan Candida albicans

\begin{tabular}{|c|c|c|c|c|c|c|}
\hline & EE & FH & FK & FM & $\mathrm{C}+$ & C- \\
\hline \multirow{3}{*}{$\mathbf{S a}$} & - & 7,79 & 8,24 & - & \multirow{3}{*}{19,10} & \\
\hline & - & 8,50 & 8,86 & - & & \\
\hline & - & 8,53 & 8,14 & - & & \\
\hline$\Sigma$ & - & 24,82 & 25,24 & - & & \\
\hline Rata - rata & - & 8,27 & 8,41 & - & & \\
\hline \multirow{3}{*}{ Ca } & - & 8,26 & 8,10 & - & \multirow{3}{*}{15,50} & \\
\hline & - & 8,18 & 7,81 & - & & \\
\hline & - & 8,10 & 8,28 & - & & \\
\hline$\Sigma$ & - & 24,54 & 24,19 & - & & \\
\hline Rata - rata & - & 8,18 & 8,06 & - & & \\
\hline \multirow{3}{*}{ St } & - & - & - & - & \multirow{3}{*}{19,62} & \\
\hline & - & - & - & - & & \\
\hline & - & - & - & - & & \\
\hline$\Sigma$ & - & - & - & - & & \\
\hline Rata - rata & - & - & - & - & & \\
\hline
\end{tabular}

\section{Keterangan :}

EE $\quad$ : Ekstrak Etanol $\quad$ FH $\quad$ :Fraksi n-Heksan

FK : Fraksi Kloroform FM : Fraksi metanol

C+ : Control Positif $\quad$ C- : Control Negatif

\section{Determinasi Sampel}

Determinasi karang lunak Sarcophyton sp., dilakukan di Fakultas Matematika dan Ilmu Pengetahuan Alam Program Studi Farmasi Universitas Sam Ratulangi. Determinasi dilakukan agar mengetahui sampel yang di ambil dan dilakukan

penelitian adalah sampel yang sesuai yaitu karang lunak Sarcophyton sp.

\section{Ekstraksi dan Fraksinasi}

Sacophyton sp. di ekstraksi dengan menggunakan metode maserasi. Metode ini digunakan karena peralatan dan pengerjaan 
yang sederhana dan mudah dilakukan. Perendaman sampel dalam maserasi dapat membuat dinding sel dari sampel pecah dan membuat senyawa-senyawa yang ada dalam sampel yang terdapat dalam sitoplasma dapat ditarik oleh pelarut. Dinding sel pecah di karenakan adanya perbedaan konsentrasi di dalam dan di luar sel. Konsentrasi di luar sel lebih tinggi dibandingkan konsentrasi di dalam sel yang rendah sehingga dinding sel pecah karena tidak bisa menahan tekanan dari perbedaan konsentrasi (Harborne, 1987).

Maserasi sampel dilakukan dengan pelarut etanol $96 \%$, karena pelarut ini memiliki kemampuan penyaring dengan tingkat popularitas yang lebar mulai dari senyawa polar, semi polar dan non polar. Proses ekstraksi dilakukan selama 3x24 jam dan setiap 24 jam ekstrak disaring kemudian dimaserasi kembali menggunakan pelarut yang baru hal ini disebut dengan remaserasi. Remaserasi dilakukan agar senyawa aktif dalam sampel dapat ditarik secara optimum (Huliselan et al, 2015). Hasil ekstrak Karang lunak Sarcophyton sp. selanjutnya diuapkan menggunakan oven dengan suhu $40^{\circ} \mathrm{C}$, tujuannya agar air dan pelarut yang tersisa dalam ekstrak akan menguap, dan juga bertujuan untuk tetap menjaga senyawa bioaktif yang terdapat dalam filtrat karena biasanya senyawa-senyawa bioaktif tidak tahan terhadap suhu tinggi (Kowal et al., 2018).

Hasil ekstrak kasar Karang Lunak Sarcophyton sp. yang telah diperoleh selanjutnya di lanjutkan ke tahap fraksinasi. Fraksinasi yang digunakan yaitu fraksinasi cair - cair berdasarkan perbedaan tingkat kepolaran dari setiap pelarut, yaitu dimulai dari pelarut n-heksan, kloroform dan metanol. Pada proses fraksinasi dilakukan pengocokan sebelum didapat 2 lapisan pelarut hal ini bertujuan agar kandungan kimia yang terdapat dalam Karang Lunak Sarcophyton sp. secara selektif dapat ditarik oleh pelarut yang digunakan. Masing- masing pelarut akan memisahkan kelompok kandungan senyawa berdasarkan tingkat kepolaran, ekstrak disari dengan pelarut yang non polar, kemudian disari dengan pelarut yang semi polar dan pelarut polar (Wewengkang et al., 2014). Pada saat fraksinasi dengan pelarut- pelarut yang berbeda kepolaran, akan terbentuk 2 lapisan, dimana pelarut dengan masa jenis yang lebih besar akan berada di bagian bawah dan pelarut dengan masa jenis kecil akan berada di lapisan atas. Kemudian fraksi yang diperoleh di uapkan dengan oven pada suhu $40^{\circ} \mathrm{C}$ dan kemudian digunakan untuk uji aktivitas antimikroba.

Dari masing-masing rendemen ini disebabkan oleh berbagai perbedaan jenis pelarut yang dipakai. Pelarut yang berbeda akan melarutkan senyawa-senyawa yang berbeda tergantung berdasarkan tingkan kepolaran. Oleh karena itu, jumlah ekstrak yang dihasilkan tergantung dari jenis pelarut yang pakai (Mujipradhana et al., 2018). Perbedaan ini disebabkan karena perbedaan jenis pelarut yang digunakan, dimana pelarut yang berbeda akan melarutkan senyawa yang berbeda, sehingga jumlah fraksi pelarut metanol memiliki rendemen paling tinggi. Hal ini menunjukan bahwa dalam senyawa karang lunak Sarcophyton sp., terdapat banyak senyawa yang bersifat polar.

\section{Uji Aktivitas Antimikroba}

Pengujian aktivitas antimikroba dilakukan dengan menggunakan metode difusi agar (difusi Kirby-Bauer yang telah dimodifikasi). Pengujian dilakukan terhadap bakteri Staphylococcus aureus yang mewakili bakteri Gram positif, Salmonella tyhpi mewakili bakteri Gram negatif dan Candida albicans yang mewakili Jamur. Metode ini dipilih karena dapat digunakan untuk melihat sensitivitas berbagai jenis mikroba terhadap antimikroba pada konsentrasi tertentu (Akhyar, 2010). Pengujian terhadap tiga jenis mikroba ini bertujuan untuk mengetahui apakah ekstrak dan fraksi dari Karang Lunak Sarcophyton sp. memiliki aktivitas antimikroba serta untuk mengetahui spektrum aktivitas antimikroba dari Karang Lunak Sarcophyton sp., apakah memiliki spektrum luas yang dapat membunuh banyak jenis mikroba atau memiliki spektrum sempit yang hanya dapat membunuh salah satu jenis mikroba saja. 
Berdasarkan hasil yang diperoleh pada pengujian ini adalah zona hambat yang disekeliling cakram berukuran $6 \mathrm{~mm}$ ( papar disc) yang ditandai oleh adanya zona bening, hal ini menunjukan adanya kepekaan mikroba terhadap ekstrak atau fraksi dari karang lunak Sarcophyton sp., dan anti biotik yang digunakan sebagai kontrol positif. Dilakukan pengamatan setelah diinkubasi pada suhu $37^{\circ}$ C selama 1 x 24 jam dengan 3 kali pengulangan pada masing-masing mikroba, pengulangan dilakukan untuk mengakuratkan hasil yang diperoleh (Mujipradana et al, 2018).

Untuk sebegai pembanding menggunakan kontrol positif dan negatif. Pada pengujian ini digunakan control positif yaitu kloramfenikol dengan spectrum kerja yang luas. Penggunaan kontrol positif berfungsi sebagai kontrol dari zat uji, dengan membandingkan diameter daerah hambat yang terbentuk (Dwijendra et al, 2014). Kontrol negatif yang digunakan yaitu metanol. Kontrol negatif digunakan untuk mengetahui ada atau tidaknya pengaruh terhadap pertumbuhan mikroba uji, sehingga dapat diketahui bahwa aktivitas yang ditunjukan oleh ekstrak atau fraksi yaitu zat yang ada dalam sampel bukan berasal dari pelarut yang digunakan.

Kriteria yang digunakan dalam penelitian ini untuk menggolongkan daya hambat dari kontrol uji dan bahan uji Karang Lunak Sarcophyton sp. menggunkana kriteria kekuatan antibakteri menurut Davis dan Stout yaitu dapat dilihat pada tabel 3 dibawah ini:

Tabel 3. Kategori Kekuatan Daya Antimikroba
Diameter Zona
Kategori
Bening (mm)

\begin{tabular}{cc}
\hline$>20$ & Sangat Kuat \\
$10-20$ & Kuat \\
$5-10$ & Sedang \\
$<5$ & Lemah \\
\hline
\end{tabular}

Berdasarkan hasil yang diperoleh pada tabel 2, pada ekstrak etanol sampel Karang Lunak Sarcophyton $s p$. terhadap bakteri Stapphylococcus aureus, Salmonella tyhpi, dan jamur Candida albicans tidak ada zona bening, hal ini menunjukkan bahwa pada ekstrak etanol sama sekali tidak ada aktivitas untuk menghambat antimikroba.

Pada Fraksi n-heksan hasil yang di dapat zona bening yang terbentuk hanya pada bakteri Stapphylococcus aureus dengan daya hambat yang dikategorikan sedang yaitu 8,27, dan jamur Candida albicans dimana daya hambatnya di kategorikan sedang yaitu 8,18. Sementara untuk bakteri Salmonella tyhpi, menunjukkan tidak adanya zona bening sama sekali, hal ini menunjukkan fraksi n-heksan pada bakteri Salmonella tyhpi tidak ada aktivitas menghambat antimikroba.

Pada fraksi klorofom hasil yang didapat zona bening yang terbentuk hanya ada pada bakteri Stapphylococcus aureus dengan daya hambat yang dikategorikan sedang yaitu 8,41 dan jamur Candida albicans dimana daya hambatnya di kategorikan sedang yaitu 8,06. Sementara untuk bakteri Salmonella tyhpi, menunjukkan tidak adanya zona bening sama sekali, hal ini menunjukkan fraksi klorofom pada bakteri Salmonella tyhpi tidak ada aktivitas menghambat antimikroba.

Pada fraksi metanol sampel Karang Lunak Sarcophyton sp. terhadap bakteri Stapphylococcus aureus, Salmonella tyhpi, dan jamur Candida albicans tidak ada zona bening, Hal ini menunjukkan bahwa pada fraksi metanol sama sekali tidak ada aktivitas untuk menghambat antimikroba.

Hasil yang didapat dari uji aktivitas antimikroba pada mikroba uji Stapphylococcus aureus, Salmonella tyhpi, dan Candida albicans, diperoleh bahwa hanya sebagian fraksi yang memiliki aktivitas untuk penghambat antimikroba dengan dikategori kan sedang, seperti pada fraksi $\mathrm{n}$ heksan dan klorofom yang hanya memiliki aktivitas menghambat yang sedang pada bakteri Stapphylococcus aureus dan jamur Candida albicans Sementara untuk bakteri Salmonella tyhpi ekstrak dan fraksi sampel Karang Lunak 
Sarcophyton sp. tidak memiliki aktivitas untuk menghambat bakteri tersebut.

\section{KESIMPULAN}

Menurut hasil penelitian sampel Karang Lunak Sarcophyton sp. Memiliki aktivitas antimikroba yang tergolong sedang pada fraksi $\mathrm{n}$ heksan dan fraksi klorofom terhadap bakteri Stapphylococcus aureus dan jamur Candida albicans Sementara untuk bakteri Salmonella tyhpi ekstrak dan fraksi sampel Karang Lunak Sarcophyton sp. tidak memiliki aktivitas antimikroba.

\section{SARAN}

Perlu dilakukan penelitian lebih lanjut terhadap Karang Lunak Sarcophyton sp. Dengan metode pengujian berbeda dan bahan uji seperti bakteri dan jamur lainnya.

\section{DAFTAR PUSTAKA}

Akhyar, 2010. Uji Daya Hambat dan Analisis KLT Bioautografi Ekstrak Akar dan Buah Bakau (Rhizophora stylosa Griff.) terhadap Vibrio harveyi. [Skripsi]. Fakultas Farmasi Universitas Hasanuddin Makassar.

Batt, C. A., \& M. L. Tortorello. 2014. Encyclopedia Food Microbiology II. Elsevier, USA.

Brooks, G. F., J. S. Butel., \& S. A. Morse . 1995. Mikrobiologi Kedokteran Jawetz, Melnick, dan Adelberg. ed. 20. Edi Nugroho (alih bahasa),1996, penerbit Buku Kedokteran, EGC. Jakarta, Indonesia.

Brooks, G. F., J. S. Butel., \& S. A. Morse. 2005. Jawetz, Melnick, Adelberg, Mikrobiologi Kedokteran, Edisi 23, diterjemahkan Hartanto, H., Jakarta, Penerbit Buku Kedokteran, EGC.

David, W. W., \& T.R. Stout. 1971. Disc plate method of microbiological assay. Journal of microbiology 22: 659665.
Dwijendra, I. M., D. S. Wewengkang., \& F. Wehantou. 2014. Aktivitas Anti bakteri dan Karakterisasi Senyawa Fraksi Spons Lamellodysidea herba cea yang diperoleh dari Teluk Manado. Pharmacon. 3(4): 1-9.

Harbone, J.B. 1987. Metode Fitokimia Penuntun Modern Menganalisis Tumbuhan Edisi Kedua. Diterjemah kan oleh Kosashi Padmawinata dan Iwang Soedira, ITB Press, Bandung.

Huda, C., \& M. Salni. 2011. Penapisan Aktifitas Antibakteri dan Bakteri Yang Berasosiasi Dengan Karang Lunak Sarcophyton sp. Jurnal Program Studi Ilmu Kelautan. Fakultas Matematika dan Ilmu Pengetahuan Alam. Universitas Sriwijaya.

Huliselan, Y. M., M. R. J. Runtuwene., \& D. S. Wewengkang. 2015. Aktivitas Antioksidan Ekstrak Etanol, Etil, Asetat, dan n-heksan dari Daun Sesewanua (Clerodendron squama tum Vahl.). Jurnal Ilmiah Farmasi 4(3) : 155-163.

Kowal, A., A. Esther., K. Nickson., K. Kurniati., Henky., \& M. Deiske. 2018. Potensi antibakteri karang lunak lobophytum sp. Dari perairan pangalisang pulau bunaken terhadap bakteri Pseudomonas aeruginosa dan Staphylococcus aureus. Jurnal Ilmiah Platax. 6(2)

Lalamentik, G. 2017. Aktivitas Antibakteri Ekstrak Karang Lunak Klyxum sp. yang Diperoleh dari Teluk Manado. [Skripsi]. Program Studi Farmasi FMIPA Universitas Sam Ratulangi, Manado. 
Mpila, D. A., Fatimawali .,\& I. W. Wiyono. 2012. Uji Aktivitas Antibakteri Ekstrak Etanol Daun Mayana (Coleus atropurpureus benth) Terhadap Staphylococcus aureus, Escherichia coli dan Pseudomas aeruginosa Secara Invitro. Pharmacon . 1(1) : 13-21.

Mujipradana, V.N., D. S. Wewengksng., \& E. Suryanto. 2018. Aktivitas Antimikroba dari Ekstrak Ascidian Herdmania momus pada Mikroba Patogen Manusia. Pharmacon. 7(3): 338-347.

Ortez, J. H. 2005. Disk Diffusion testing in manual of antimicrobial susceptib ility.

Pasodung, P.A.,. F. Losung., D.E. Angkow., R. Lintang., \& D. A. Sumilat. 2018. Uji Aktivitas Antibakteri Spons Plakirtis Sp. Yang Dikoleksi Dari Perairan Bunaken . Jurnal Pesisir Dan Laut Tropis. 1(1) : 44-51.
Sawant, S., D. Youssef., A. Mayer,. P. Sylvester., V. Wall., M. Arant., \& K. El-Sayed. 2006. Anticancer And Anti-Inflamantory Sulphur-Containi ng Semisynthetic Derivatives Of Sarcophine. Chem, Pharm, Bull, 54(8) : 1119-1123.

Tortora, G. J., B. R. Funke., \& C. L Case. 2001. Microbiology : An Introduc tion, 7th edition, San Fransisco : Benjamin Cummings, p. 125.

Wewengkang, D.S., D. A. Sumilat., \& H. Rotinsulu. 2014. Karakterisasi dan Bioaktif Antibakteri Senyawa Spons Haliclona sp. dari Teluk Manado. Jurnal LPPM Bidang Sains dan Teknologi . 1(1)

Wibowo, S. 2010. Ilmu Pangan Nutrisi dan Mikrobiologi edisi ke-2 . Rajawali Press, Jakarta 